\title{
SUSTAINABILITY: MASONRY'S CORNER STONE OR STUMBLING BLOCK?
}

\section{J. Gregg BORCHELT' email}

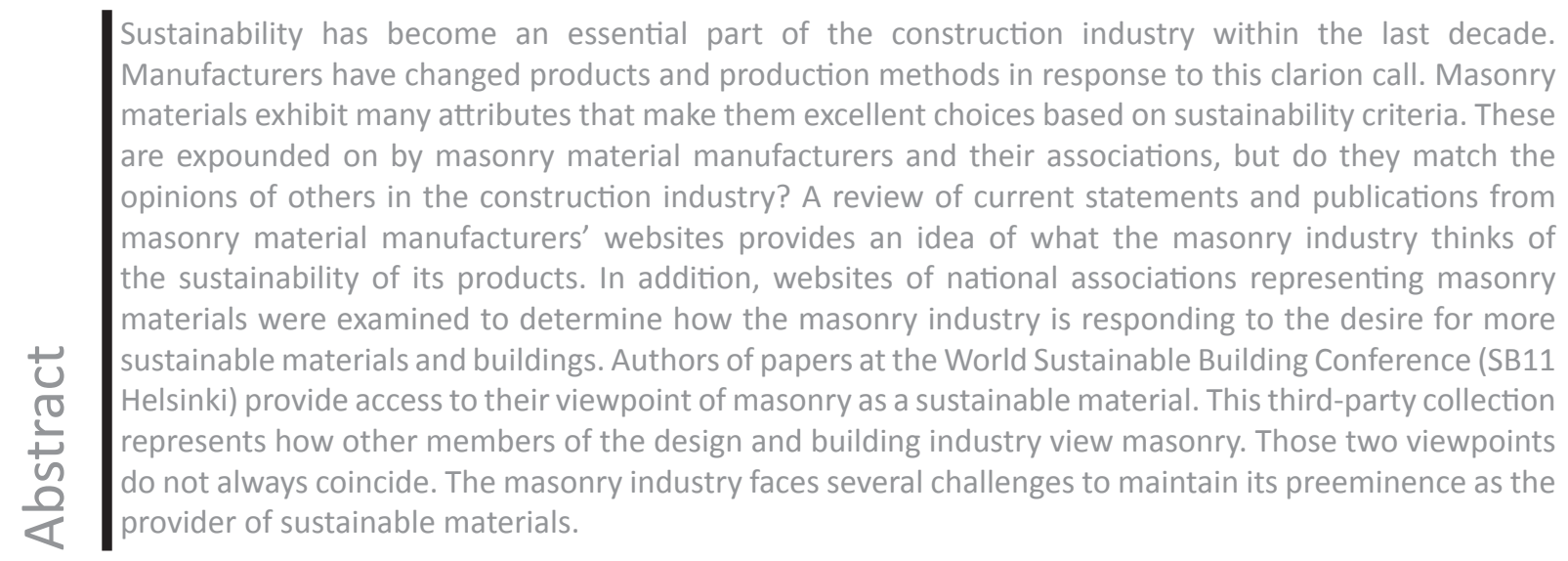

Keywords: sustainable, masonry, opinions, designers, manufacturers, challenges. 


\section{INTRODUCTION}

Of course masonry is a sustainable material! At least it certainly was in the beginning. Stone was collected and used nearly as is. The oldest manufactured construction material is brick and they were made at the jobsite. Sun and wood (renewable, non-fossil fuels) dried and fired these brick. Cementitious materials for mortar were made from oyster shells, easily obtained limestone and pozzolans from volcanic ash, all gathered nearby. Ground brick was also used as a pozzolan, recycling a waste product. Sand came from nearby streams. Concrete masonry units were first known as "cinder block" because they were made from those recycled waste products. Concrete block was made by hand, cured at ambient conditions and near the jobsite. The oldest extant buildings are masonry and are arguably the most sustainable.

But production of units and mortar materials became more efficient. Brick plants were located near clay and shale deposits. Cement companies built large kilns near layers of limestone. New fuels were used, often non-renewable. With a desire for aggregate with more uniform properties the cinder was replaced in concrete masonry with manufactured aggregate. Better roads and trucks permitted longer shipping distances. A siding for rail shipping became a necessity for a manufacturing facility.

Now we have additional considerations for manufacturing and delivering masonry materials. Requirements for buildings related to sustainability and to reduce the impact on the environment have been adopted by law or by practice in virtually all developed countries. The actual regulations or sustainable rating of components or buildings vary somewhat, but they do influence the selection of construction materials and the specific product or unit considered. Green is everywhere.

Certainly the masonry material manufacturers have responded to this demand. Manufacturing facilities have been enhanced to use less energy and increase production with less material loss. Recycled materials often replace conventional virgin raw materials. New types of units, made primarily from recycled materials and with new processes, vie for acceptance. Renewable energy has supplemented or replaced fossil fuels. Unit configurations have been changed and components reduced in size to require fewer raw materials. Depleted quarries and mining sites have been returned to functional sites for office parks, recreation, residential development and wildlife sanctuaries.

We must also pay attention to how masonry buildings are considered in these sustainability requirements. The effect of thermal mass in reducing energy consumption must be properly utilized. Inherent fire resistance and lack of refinishing exposed surfaces reduce the need for other materials. Structure, enclosure, finish, temperature control and fire protection are available in one material. Proper credit to the longevity of masonry buildings must not be ignored.

\section{MATERIAL MANUFACTURERS OPINION OF SUSTAINABILITY OF PRODUCTS}

The manufacturers of masonry materials know that they must continue to expound on the sustainability virtues of their company and many of their websites include statements related to company actions in this area. Companies also tout the green properties of their products. Some representative examples from a variety of countries and materials are:

Source: http://www.ibstock.com/news-15.asp

England, brick manufacturer

Ibstock was also the first brickmaker to achieve the environmental management standard ISO 14001 across all of its sites, demonstrating why it is possibly the 'greenest' brick manufacturer in the UK.

Andrew Halstead-Smith, marketing manager at Ibstock commented: "Ibstock has long been at the forefront of sustainable development and the environment and as a company is continually looking to improve these green credentials. Our new 'Sustainable Product Guide' is an excellent example of just how much can be achieved when building with brick."

Source:http://www.trenwyth.com/trenwyth_ commitment.asp

United States, concrete block manufacturer

Trenwyth has developed architectural concrete masonry units that contain a significant amount of recycled content and may earn $L E E D \AA$ points.

Source: http://www.australbricks.com/au/nsw/ Sustainability/Embodied-energy

Australia, brick manufacturer 
Austral Bricks:The embodied energy inherent in bricks should be considered as an investment that can lead to long term environmental benefits through;

- $\quad$ Reducing the need for artificial heating and cooling when used in combination with passive design principles;

- $\quad H a v i n g$ a long life and being durable, reducing the need to reinvest in embodied energy; and

- $\quad$ And being colourfast and virtually maintenance free, reducing ongoing energy usage. In addition to the obvious environmental benefits of bricks, energy bills are reduced providing considerable savings for the home owner.

Source:http://www.cemexusa.com/Sustainability/ SustainableConstruction.aspx

United States, cement manufacturer

CEMEX aims to lead in sustainable construction by developing building products and solutions that have significant positive sustainability attributes and contribute to the transformation of the construction sector.

Source: http://www.wienerberger.com / sustainability

Austria, brick manufacturer

We view sustainability as an integral part of our business and an important factor for Wienerberger's financial success. For these reasons, we have firmly anchored sustainability in our corporate strategy. The 2010 sustainability report provides a wide range of information on Wienerberger's challenges and successes in key areas - environmental protection in production, sustainable products, employees and social responsibility.

Wienerberger building materials create sustainable structures with natural raw materials and guarantee a healthy interior climate. Cost-effective building materials make it possible to construct affordable housing that is highly resistant to both fire and earthquakes. Wienerberger products are part of system solutions for sustainable construction.

Source: http://www.boralbricks.com/cms/ Sustainability/2.html

Australia, brick, manufacturer

WHY BORAL ${ }^{\circledR}$ ?

Alternative Fuel Sources - Our newest state-of-theart plants siphon methane gas from landfills, while many of our plants use renewable fuel resources such as wood-waste materials.

Better Manufacturing Processes - Bora ${ }^{\circledR}$ goes beyond compliance to further reduce waste and minimize adverse environmental effects.
Wider Distribution Network - Our 21 strategically placed manufacturing plants significantly reduce transportation costs and fuel consumption.

WHY BRICK?

Abundant Raw Materials - Boral ${ }^{\circledR}$ bricks are made from two of the most abundant natural materials on the planet: clay and shale.

Earth-friendly Harvesting - Both clay and shale are harvested from the earth by a process that has minimal long-term environmental effects on the land. Most clay mining sites are reclaimed as wetlands or parks. An Unsurpassed Life Cycle - Bricks are long-lasting, completely recyclable and biodegradable.

Energy Efficient - Brick construction provides the advantages of thermal mass, holding temperatures constant longer than other materials, resulting in interior environments with greater energy efficiency.

Source: http://basalite.com/About_Us_Environment. html

United States, concrete block manufacturer

As the largest western regional concrete products production and distribution company in North America, Basalite Concrete Products is committed to reducing our environmental footprint. The company is a proud supporter of the United States Green Building Council and is committed to reducing the carbon footprint of our business by $15 \%$ by 2020, as compared to our 2009 baseline. To reduce our emissions, we have accelerated the replacement/ retrofit of our off-road diesel \& gasoline-powered material handling fleet to comply with California's $A B$ 32/Global Warming Solutions Act; and are installing new, state-of-the-art concrete curing systems in our plants. We are also reducing the energy we use in our facilities, exploring the use of renewable energy, and installing process-water recycling systems in facilities that have been using settling/holding ponds.

Source: http://www.corobrik.com/enviroment

South Africa, brick manufacturer

Corobrik is committed to a holistic approach to environmental sustainability where all the activities in the business are based on sound environmental practices.

At operational level, Corobrik manages it's quarrying and manufacturing processes within a sustainable development framework. This includes social and labour plans within the framework of the new order mining rights, approved environmental management plans for each quarry and manufacturing process, the concurrent rehabilitation of all quarries during annual quarrying operations and the final rehabilitation and re-use of worked out quarries as a nature reserve surrounding a pollution free dam, recreational area, landfill site or commercial/residential development. 
Containing and reducing the embodied energy resultant of the firing processes, is a key objective. To this end, Corobrik is committed to the greater use of cleaner burning fuels, more effective use of energy and the employment of technological innovations able to achieve incremental reductions in Corobrik's carbon footprint both at time of manufacture, during delivery of its products to site and in application.

Source: http://calstarproducts.com/sustainability/
United States, fly ash brick manufacturer

Producing brick from recycled fly ash consumes less energy and emits less $\mathrm{CO} 2$ because it does not require firing to harden the masonry units. Nor is any cement, which also has a large carbon footprint. As a result, the CalStar green brick solution represents 85\% lower embodied energy and 85\% lower CO2 emissions than traditional fired clay brick.

\section{MASONRY ASSOCIATIONS OPINION OF SUSTAINABILITY OF PRODUCTS}

The associations that represent those materials concentrate more on the properties of the products. Some list publications that go into analysis and comparisons. Others provide text for information. Examples from around the world are:

Source: http://www.gobrick.com

United States, brick manufacturers and distributors BIA Technical Note 48 - Sustainability and Brick

BIA Brick in Home Building - The Bottom Line on Brick's Role in Sustainability and Green Building Design

BIA Brick in Home Building - Using Brick for Green Building Design and Sustainable Residences

BIA Builder Note 5 - Brick: Green Building Design and Sustainability

BIA Builder Note 6 - How Brick Can Help You Build Green, Efficient Homes That Your Customers Want

BIA Brick Brief-Recycled Content in Green Building Rating Systems - Certification and Credit

BIA Brick Brief - Regional Materials in Green Building Rating Systems - Calculating Credit

Source: http://www.claybrick.org.za/download. php?list.15

South Africa, brick manufacturers

Energy Efficiency Graphs

Achieving Optimal Thermal Comfort

Source: http://www.thinkbrick.com.au/why-arebricks-sustainable-4/

Australia, brick manufacturers

Bricks have thrived over thousands of years because of their longevity, durability and a number of factors that contribute to their inherent sustainability. They require minimal maintenance, create highly energy efficient buildings and perform multiple functions, reducing environmental impacts from other materials. This section of the website outlines research and collaboration between Think Brick Australia and independent groups to help you make informed decisions about the sustainability of clay bricks.
Long before 'sustainability' was a priority, builders and home owners were using clay bricks because they lasted forever and required almost no maintenance over time. Brick buildings are strong, durable and can resist extreme weather events through fireresistant construction and resistance to impacts and wind-borne debris.

Now, more than ever, climate design is a critical element in the modern design process.

Think Brick Australia commissioned a TOTAL Life Cycle Assessment (LCA) of the brick industry to quantify the environmental impact of clay bricks.

Source: http://www.ncma.org/Pages/default.aspx United States, concrete masonry manufacturers TEK 6-6B Determining the Recycled Content of Concrete Masonry Products

TEK 6-9C Concrete Masonry and Hardscape Products in LEED 2009Program

Source: www.cba-blocks.org.uk

England, concrete masonry manufacturers

Versatile, durable and strong; completely fire resistant; Excellent sound insulation; Inherent thermal mass acts as heat store; Recyclable; Cost effective

New research shows that over their lifetime, concrete homes win the carbon battle hands down.

Source: http://www.aircrete.co.uk/benefits/ sustainable-credentials.html

England, autoclaved aerated concrete masonry manufacturers

Aircrete's unique sustainable benefits.

- 'A+' rated in the BRE Green Guide

- BES 6001:2008 certified

- Can help meet all levels of the Code for Sustainable Homes

- $\quad$ High recycled content

- $\quad$ Materials are UK sourced

- Minimum 60 years lifespan as per an

independent BRE assessment

- $\quad$ High level of thermal insulation

- $\quad$ Contributes to thermal mass 
- Low to nil maintenance requirements over their lifespan

- $\quad$ Aircrete can be recycled

Source: www.cement.org

United States, cement manufacturers

Cement Manufacturing Sustainability Program

Functional Resiliency

A Track Record of Sustainability

Source: http://www.brick.org.uk/about-the-brickdevelopment-association/why-brick/

England, brick manufacturers

The BRE's latest Green Guide to Specification has assigned the highest possible accreditation $A+$ to every external wall it rated that contained brickwork.

Bricks are a versatile and durable building material, with excellent life cycle performance, energy efficiency, high thermal mass and responsible manufacturing. Brick and brick buildings are sustainable because they:

- $\quad$ Are highly durable;

- $\quad$ Offer long term life performance;

- $\quad$ Are low maintenance;

- $\quad$ Are energy efficient;

- Provide healthy and comfortable environments; and

- $\quad$ Are recyclable.

Sustainability is often compressed into a consideration of energy use defined as the emission of CO2. The brick industry measures this annually and also reports on it under the EU Emissions Trading Scheme.

Source: http://www.buildingstoneinstitute.org/ sustainability.html

United States, building stone suppliers

Significant work has been done by the NSC to gather accurate data characterizing the environmental impacts of the natural stone industry. The following reports can be downloaded here and have been provided by the Natural Stone Council. They are organized into four categories: Life Cycle Datasets, Best Practices, Case Studies, and Material Fact Sheets.

Stone Federation Sustainability Brochure, Natural Stone. The Oldest Sustainable Material

Key criteria mentioned in these websites are:

- $\quad$ Embodied energy of units and walls;

- $\quad$ Carbon footprint of units and walls;

- Durability to weather;

- Impact resistance;

- $\quad$ Reduced maintenance;

- $\quad$ Life cycle inventory;

- $\quad$ Long life span;

- $\quad$ Energy usage over building life;

- $\quad$ Thermal mass;

- $\quad$ Recycled materials;

- $\quad$ Reuse or recycle; and

- Air quality.

\section{MASONRY ASSOCIATIONS SUSTAINABILITY CONCERNS}

In order to obtain more firsthand information on sustainability and the masonry industry a series of questions were sent to national masonry material associations. Many responded with a reference to their website, thus the preceding list of website content. Associations from only three countries responded. The questions and responses are given in Table 1.

Table 1: Material associations response to sustainability concerns.

1. What changes have been made in the manufacturing of masonry materials to reduce their impact on the environment?

Concrete Masonry Association Use of lightweight aggregate to reduce weight

Argentina

Concrete Masonry Association $\quad$ Replacing cement with fly ash, slag cement, ground glass, etc.;

United States

Incorporating recycled materials: crushed concrete, bottom ash, glass, etc.;

More sophisticated curing systems to reduce cement and energy;

injection of captured $\mathrm{CO} 2$ into the concrete mix

Clay Masonry Association

Austria
Reduction of energy consumption in production process;

Use of fuels with lower CO2 emission;

Replace fossil fuel with renewable energy;

Lighter products (more voids in the bricks, higher porosity of clay

blocks);

Replace mined raw materials with secondary materials 
Table 1: Continued...

\begin{tabular}{|c|c|}
\hline \multicolumn{2}{|c|}{ 2. What is the most successful strategy you use to promote masonry's sustainability? } \\
\hline $\begin{array}{l}\text { Concrete Masonry Association } \\
\text { Argentina }\end{array}$ & $\begin{array}{l}\text { Sustainability is not much of an issue. The acceptance of structural } \\
\text { masonry is more of an issue. }\end{array}$ \\
\hline $\begin{array}{l}\text { Concrete Masonry Association } \\
\text { United States }\end{array}$ & Promote masonry's durability and resiliency \\
\hline $\begin{array}{l}\text { Clay Masonry Association } \\
\text { Austria }\end{array}$ & $\begin{array}{l}\text { Active communication with designers and owners about the } \\
\text { masonry's sustainable properties }\end{array}$ \\
\hline \multicolumn{2}{|c|}{ 3. Is more emphasis placed on the masonry unit or the wall assembly? } \\
\hline $\begin{array}{l}\text { Concrete Masonry Association } \\
\text { Argentina }\end{array}$ & $\begin{array}{l}\text { It is a common mistake to place the unit on the same level of the wall } \\
\text { assembly. }\end{array}$ \\
\hline $\begin{array}{l}\text { Concrete Masonry Association } \\
\text { United States }\end{array}$ & $\begin{array}{l}\text { Suppliers of a given material are primarily focused on the } \\
\text { sustainability attributes of their own material. }\end{array}$ \\
\hline $\begin{array}{l}\text { Clay Masonry Association } \\
\text { Austria }\end{array}$ & $\begin{array}{l}\text { It is our strategy to shift more from a product related approach to a } \\
\text { system related approach, which means functional units, } 1 \mathrm{~m}^{2} \text { of wall. } \\
\text { We now and promote concepts for houses. }\end{array}$ \\
\hline
\end{tabular}

4. Do governmental regulations for sustainable construction recognize the properties of masonry (such as thermal mass, longevity, reduced maintenance, etc.)

Concrete Masonry Association Not in Argentina. The governmental regulations are very weak but Argentina the province of Buenos Aires has issued a new regulation about the thermal mass performance of a public or private housing with the only objective to reduce energy consumption.

Concrete Masonry Association Only to a degree. The U.S. building codes do recognize thermal mass United States by requiring lower R-values for prescriptive compliance options. However, complicated modelling is rarely conducted that might allow mass properties to truly be used. Longevity is not recognized. The new International Green Conservation Code is attempting to consider longevity, but has not yet arrived at a reliable method to achieve and to satisfactorily document.

Clay Masonry Association We have to fight to bring our aspects into legislation and Austria standardization. We have just launched a research project about longevity and service life time. There are many studies proving the benefits of high thermal mass construction, especially in summer time.

\begin{tabular}{|c|c|}
\hline \multicolumn{2}{|c|}{ 5. What do you see as the most vulnerable aspect of masonry with respect to sustainability? } \\
\hline $\begin{array}{l}\text { Concrete Masonry Association } \\
\text { Argentina }\end{array}$ & $\begin{array}{l}\text { For clay masonry it is the CO2 liberated in production. This is not the } \\
\text { case of concrete masonry }\end{array}$ \\
\hline $\begin{array}{l}\text { Concrete Masonry Association } \\
\text { United States }\end{array}$ & $\begin{array}{l}\text { For concrete masonry, negative perceptions regarding CO2 emissions } \\
\text { associated with cement manufacturing when carbon footprint is used } \\
\text { as the method of evaluation - especially when shorter life spans are } \\
\text { used in such evaluations. } \\
\text { Life-cycle attributes, our best messaging point, is not documented } \\
\text { well enough into evaluation systems to enable the industry to } \\
\text { recognize its full potential. } \\
\text { Black-box LCA software programs, based on outdated or average data, } \\
\text { may not put the best foot forward for masonry systems. } \\
\text { Over-reliance on R-Value- Variables affecting energy usage in } \\
\text { buildings is not well understood. Most designers regress to simplest } \\
\text { compliance options deferring to higher R-value systems. }\end{array}$ \\
\hline
\end{tabular}


Table 1: Continued...

\begin{tabular}{|c|c|}
\hline $\begin{array}{l}\text { Clay Masonry Association } \\
\text { Austria }\end{array}$ & $\begin{array}{l}\text { For us the most important aspects of sustainability of clay } \\
\text { construction products are: } \\
\text { - } \quad \text { Longevity } \\
\text { - } \quad \text { High and stable economic value } \\
\text { - } \quad \text { Healthy indoor air quality } \\
\text { - } \quad \text { High energy efficiency of clay buildings } \\
\text { Clay products and buildings made out of them are part of our } \\
\text { cultural heritage }\end{array}$ \\
\hline
\end{tabular}

6. Do you have or foresee a method of measuring the sustainability characteristics of construction materials establishing a foothold? If so, what is it?

Concrete Masonry Association No

Argentina

Concrete Masonry Association

United States

Not yet. Jury seems to be out as to whether carbon footprint, embodied energy, global warming potential, or other methods of measurement will become the most consistent benchmark.

Clay Masonry Association In the European Union we are evaluating the so-called Environmental Austria Product Declaration (EPD). These will soon become legally binding. The methodology of such EPDs is regulated by a CEN standard. On the building level there are assessment methodologies in different stages of development. Unfortunately there is no harmonized approach. Therefore we have several systems on the market (BREEAM in UK, LEED from the US, which is also quite popular in Europe, DGNB in Germany, HQE in France, TQ-B in Austria). What is common in all these assessment tools is the holistic approach, taking into account all aspects of sustainability: economical, ecological and socio-cultural aspects as well was as the technical performance. For this reason we support the holistic approach which is very positive for us compared to a mere energy related approach.

\section{SB11 AUTHORS PAPERS ON MASONRY}

The World Sustainable Building Conference (SB11 Helsinki) was held in October 2011. It addressed new opportunities for improving quality of life, mitigating the effects of climate change and making new business. During four days 310 oral presentations were delivered and 200 posters shown. While papers addressing masonry were not a specific topic of the themes or forums, masonry was frequently mentioned. This often occurred because masonry is ubiquitous; used in virtually every country. Masonry was frequently used as a basis of comparison for performance criteria or was part of buildings discussed in case studies.

The following topics and statements in SB11 papers provide an insight as to what designers and planners think of masonry's sustainability. For each sustainability topic the papers are identified as being favorable to (Positive) or against (Negative) the use of masonry. In some papers both positive and negative attitudes were included. These are identified as Neutral. Search words to locate papers were: adobe, brick, concrete block, masonry, mortar, stone.
Topic: Recycling demolished masonry, Use of waste materials:

Positive: Walden and Fabian-Lopez (2011), Kuittinen and Kaipainen (2011), Gallera and Tabatcheik (2011), Boehme (2011) and Huang and Chou (2011).

Topic: Use of masonry for thermal mass:

Positive: Benedetti et al. (2011), Bennetts (2011), Da Silva and Ramos (2011), Dumitrascu (2011), Kozak (2011), Leister and Abu-Hijleh (2011), Lütkemeyer \& Krause (2011), Woo (2011), Varini (2011), Versele (2011), Sacht, Bragança and Almeida (2011) and Molist (2011)

Negative: Keeffe and McHugh (2011).

Topic: Embodied energy and CO2 emissions:

Positive: Hatherley and Littlewood (2011) and Peng (2011).

Neutral: Suomi and Kassi (2011).

Negative: Bragança and Mateus (2011), Kaido \& Oka (2011), Mateus (2011), Roos and Gorgolewski (2011), Soikkeli (2011) and Toller (2011).

Topic: Life cycle assessment: 
Positive: Drebs and Fortelius (2011), Gallera and Tabatcheik (2011), Mišĉević (2011) and Ozuna and Rivera (2011).

Negative: Debacker (2011), Mateus (2011), Roos and Gorgolewski (2011) and Toller (2011).

Topic: Durability, Life of structures:

Positive: Duarte (2011), Hjortsberg (2011), Mazzola (2011) and Schneider (2011).

Negative: Keeffe and McHugh (2011)

Some particularly vexing comments include:

"[...] the replacement of masonry walls and concrete structures for steel framing systems with closure in dry wall can be mentioned." (DOS SANTOS, 2011).
"[...] the original façade was load-bearing brick and block [...]. The new façade was designed to be replaced every 25 years (and possibly more frequently) so it could keep up with the changing climate." (KEEFFE; MCHUGH, 2011)

"[...] Technologies using bricks, cement and steel on a large scale should be discouraged." (MANJUNATH, 2011).

"Compressed earth blocks offer an option that consumes less energy than fired brick and concrete [...]" (SUOMI; KASSI, 2011).

\section{CHALLENGES TO THE MASONRY INDUSTRY AND CONCLUSIONS}

There is not complete agreement between the manufacturers and their associations with designers on sustainable topics. Both the masonry industry and the designers agree that Masonry is durable, has low maintenance and a long life span. They also agree that masonry's thermal mass will reduce energy usage. Further agreement is that masonry can be made from recycled materials and may be recycled itself. However, the designers do not think that masonry has a low carbon footprint or low embodied energy. The life cycle assessment and life cycle inventory aspects of masonry, while praised by the masonry industry, are praised by some designers and denigrated by others. These differences indicate that the masonry industry must continue to emphasize the sustainable virtues of masonry.

Following are some comments and recommendations. Life Cycle Assessment programs have been written without much input from manufacturers on parameters used in production and construction. The masonry associations should gather these data and make them available.

Life Cycle Assessment and Product Environmental Footprint criteria should include as many damage categories as possible in the analysis.

Designing buildings for the longest life span will improve the environment and benefit masonry. Encourage green building rating systems to include durability in their criteria.

Thermal mass does not fare well in comparison to more insulation. Mass costs more to install and needs occupant assistance for best use.
Passive means of energy efficiency, often in combination with, newer control strategies, such as photovoltaic panels or active facades, provide opportunities for masonry. Designers often ignore a more traditional, less expensive approach when looking for the next best thing.

Utilization of mass in an energy analysis is not easily accomplished and should be addressed. Case studies indicate good performance of high mass buildings.

Masonry materials are easily recycled and using recycled materials to produce masonry materials is an accepted approach.

Manufacturers of masonry products have adapted their production methods to reduce the impact on the environment. They should continue to search for these accomplishments and proclaim what they have done.

Many masonry products do have a high embodied energy and it is often used as an argument against them. Manufacturers should continue to reduce the energy component of production.

Increased competition between masonry units that have different environmental attributes due to materials and production method will become more prevalent.

History demonstrates the longevity of masonry buildings, but this may be threatened by the change from all masonry walls to walls with masonry as one of several components.

The multiple benefits of masonry will keep it as a viable construction material for generations. 


\section{REFERENCES}

All references are from the World Sustainable Buildings Conference 2011, Helsinki, October 2011. Each is identified by Session. See http://www.sb11.org/sb11-helsinki/home.html.

BENEDETTI, C. et al. Natural ventilation and traditional architectonical devise: physical analysis of badgir structure. (airflow extracting tower). In: WORLD SUSTAINABLE BUILDINGS CONFERENCE, 2011, Helsinki. Proceedings... Helsinki: RIL, 2011. Theme 3: Sustainability in developing countries.

BENNETTS, R. Architectural Quality and Sustainability. In: SB10 PRAGUE - CENTRAL EUROPE TOWARDS SUSTAINABLE BUILDING 'FROM THEORY TO PRACTICE', 2010, Prague. Proceedings... Prague: Central Europe towards Sustainable Building, 2011. Prague Best paper, 2011.

BRAGANÇA, L.; MATEUS, R. Improving the design of a residential building using the SBToolPT methodology - a case study. In: WORLD SUSTAINABLE BUILDINGS CONFERENCE, 2011, Helsinki. Proceedings... Helsinki: RIL, 2011. Theme 4: Sustainable processes and eco-efficient technologies.

BOEHME, L. RecyMblock - application of recycled mixed aggregates in the manufacture of concrete construction blocks. In: WORLD SUSTAINABLE BUILDINGS CONFERENCE, 2011, Helsinki. Proceedings... Helsinki: RIL, 2011. Theme 4: Sustainable processes and eco-efficient technologies.

DA SILVA, J. M.; RAMOS, A. F. The Energetic Rehabilitation as a Sustainable Factor. In: WORLD SUSTAINABLE BUILDINGS CONFERENCE, 2011, Helsinki. Proceedings... Helsinki: RIL, 2011. Theme 4: Sustainable processes and eco-efficient technologies.

DEBACKER, W. Improving the environmental impacts of a typical Flemish retirement home: a life cycle approach. In: WORLD SUSTAINABLE BUILDINGS CONFERENCE, 2011, Helsinki. Proceedings... Helsinki: RIL, 2011. Theme 4: Sustainable processes and eco-efficient technologies.

DOS SANTOS, A. Dematerialization of the built environment. In: WORLD SUSTAINABLE BUILDINGS CONFERENCE, 2011, Helsinki. Proceedings... Helsinki: RIL, 2011. Theme 2: Well Being in Cities and Urban Environments.

DREBS, A. J.; FORTELIUS, C. Observed and Simulated Town Energy Balance Parameters in Helsinki, Finland, 2009/2010. In: WORLD SUSTAINABLE BUILDINGS CONFERENCE, 2011, Helsinki. Proceedings... Helsinki: RIL, 2011. Theme 1: World Resources.

DUARTE, M. D. L. Sustainable Design Strategies in Industrial Buildings Refurbishment: A Case Study in Lisbon. In: WORLD SUSTAINABLE BUILDINGS CONFERENCE, 2011, Helsinki. Proceedings... Helsinki: RIL, 2011. Theme 4: Sustainable processes and eco-efficient technologies.

DUMITRASCU, A. Principles of sustainable development and architectural design. In: WORLD SUSTAINABLE BUILDINGS CONFERENCE, 2011, Helsinki. Proceedings... Helsinki: RIL, 2011. Theme 3: Sustainability in developing countries.

GALLERA, I.; TABATCHEIK, A. S. Social Housing: Constructive Strategies Aimed for Sustainability in Brazil. In: WORLD SUSTAINABLE BUILDINGS CONFERENCE, 2011, Helsinki. Proceedings... Helsinki: RIL, 2011. Theme 4: Sustainable processes and eco-efficient technologies.

HATHERLEY, S.; LITTLEWOOD, J. Affordable Dwellings Following Low Carbon and Ecological Principles, in Rural Locations in Wales. In: WORLD SUSTAINABLE BUILDINGS CONFERENCE, 2011, Helsinki. Proceedings... Helsinki: RIL, 2011. Theme 2: Well Being in Cities and Urban Environments.

HJORTSBERG, M. Description of the Swedish building stock using material from a Swedish Statistical Survey of 1800 Buildings. In: WORLD SUSTAINABLE BUILDINGS CONFERENCE, 2011, Helsinki. Proceedings... Helsinki: RIL, 2011. Theme 1: World Resources.

HUANG, R. Y.; CHOU, H. Y. Development of an Appraisal System for Green Demolition. In: WORLD SUSTAINABLE BUILDINGS CONFERENCE, 2011, Helsinki. Proceedings... Helsinki: RIL, 2011. Theme 6: Social sustainability and environmental ethics. 
KAIDO, S.; OKA, T. Comparison of energy and CO2 emission associated with building materials between Japan and the U.S. and China. In: WORLD SUSTAINABLE BUILDINGS CONFERENCE, 2011, Helsinki. Proceedings... Helsinki: RIL, 2011. Theme 4: Sustainable processes and eco-efficient technologies.

KEEFFE, G.; McHUGH, I. Climate Adaptation: The future of extra-care housing for the elderly in the United Kingdom. In: WORLD SUSTAINABLE BUILDINGS CONFERENCE, 2011, Helsinki. Proceedings... Helsinki: RIL, 2011. Theme 2: Well Being in Cities and Urban Environments.

KOZAK, D. et al. Design Process of the Environment Low-Impact Demonstrative Project: Interpretation Center Canadon Del Duraznillo, Argentina, Patagonia. PARC - Pesquisa em arquitetura e construção, Campinas, v. 1, n. 6, 2011. Sao Paulo Best Papers, 2011.

KUITTINEN, M.; KAIPAINEN, S. Challenges in the Environmental Assessment of Humanitarian Construction: Case study from school reconstruction project in Haiti. In: WORLD SUSTAINABLE BUILDINGS CONFERENCE, 2011, Helsinki. Proceedings... Helsinki: RIL, 2011. Theme 3: Sustainability in developing countries.

LEISTER, A.; ABU-HIJLEH, B. Energy Performance of Public Housing Buildings in Sao Paulo, Brazil An Evaluation of the Current Design Practices. PARC - Pesquisa em arquitetura e construção, Campinas, v. 1, n. 6, 2011. São Paulo Best Papers, 2011.

LÜTKEMEYER, I.; KRAUSE, J. Energy-Plus Primary School, Hohen Neuendorf, Germany. In: WORLD SUSTAINABlE BUILDINGS CONFERENCE, 2011, Helsinki. Proceedings... Helsinki: RIL, 2011. 6 p.

MAZZOLA, E. M. Regenerate suburban districts - proposal for the "ground-scraper" Corviale in Rome. In: WORLD SUSTAINABLE BUILDINGS CONFERENCE, 2011, Helsinki. Proceedings... Helsinki: RIL, 2011. Theme 4: Sustainable processes and eco-efficient technologies.

MANJUNATH, N. Bamboo Houses - Nature's way of solving Global Housing Problem. In: WORLD SUSTAINABLE BUILDINGS CONFERENCE, 2011, Helsinki. Proceedings... Helsinki: RIL, 2011. Theme 4: Sustainable processes and eco-efficient technologies.

MATEUS, R. Life-cycle Assessment of different building technologies for partition walls - contribution to future developments on interior partition concepts. In: WORLD SUSTAINABLE BUILDINGS CONFERENCE, 2011, Helsinki. Proceedings... Helsinki: RIL, 2011. Theme 3: Sustainability in developing countries.

MIŠĈEVIĆ, L. Energy Efficiency as the Basic Integration Element of Sustainable Architecture. In: WORLD SUSTAInABle BUILDingS CONFEREnCE, 2011, Helsinki. Proceedings... Helsinki: RIL, 2011. Theme 4: Sustainable processes and eco-efficient technologies.

MOLIST, L. G. Proposal for sustainable building in temperate climates. In: WORLD SUSTAINABLE BUILDINGS CONFERENCE, 2011, Helsinki. Proceedings... Helsinki: RIL, 2011. Theme 4: Sustainable processes and ecoefficient technologies.

OZUNA, A.; RIVERA, J. Sustainable Construction in Colombia: Main Actors and Implementation. In: WORLD SUSTAInABle BUildingS CONFEREnCE, 2011, Helsinki. Proceedings... Helsinki: RIL, 2011. Theme 3 : Sustainability in developing countries.

PENG, B. Life Cycle Energy Consumption and CO2 Emissions of Buildings: An Overview and Case Studies in Beijing In: WORLD SUSTAINABLE BUILDINGS CONFERENCE, 2011, Helsinki. Proceedings... Helsinki: RIL, 2011. Theme 1: World Resources.

ROOS, R.; GORGOLEWSKI, M. Multi-Criteria Assessment of High Performance Residential Building Envelope Typologies in Canada. In: WORLD SUSTAINABLE BUILDINGS CONFERENCE, 2011, Helsinki. Proceedings... Helsinki: RIL, 2011. Theme 4: Sustainable processes and eco-efficient technologies.

SACHT, H. M.; BRAGANÇA, L.; ALMEIDA, M. Façade Modules for Eco-Efficient Refurbishment of Buildings: Trombe Wall Thermal Performance in different Portuguese Climates: Bragança, Coimbra, Évora and Faro. In: WORLD SUSTAINABLE BUILDINGS CONFERENCE, 2011, Helsinki. Proceedings... Helsinki: RIL, 2011. Theme 4: Sustainable processes and eco-efficient technologies.

SCHNEIDER, B. Inspired by the past-built for the future-appreciated living Conversion and redevelopment of a former electrical substation into 50 residential units with meeting points Ludwigshafen, Germany. In: 
WORLD SUSTAINABLE BUILDINGS CONFERENCE, 2011, Helsinki. Proceedings... Helsinki: RIL, 2011. Theme 2: Well Being in Cities and Urban Environments.

SOIKKELI, A. Carbon Neutral Renovation of Existing Suburban Building Stock. In: WORLD SUSTAINABLE BUILDINGS CONFERENCE, 2011, Helsinki. Proceedings... Helsinki: RIL, 2011. Theme 4 Sustainable processes and eco-efficient technologies.

SUOMI, M.; KASSI, T. Participatory Design Process of a Youth Centre in Phnom Penh, Cambodia. In: WORLD SUSTAINABLE BUILDINGS CONFERENCE, 2011, Helsinki. Proceedings... Helsinki: RIL, 2011. Theme 6: Social sustainability and environmental ethics.

TOLLER, S. Indicators for environmental monitoring of the Swedish Building and Real Estate Management Sector. In: WORLD SUSTAINABLE BUILDINGS CONFERENCE, 2011, Helsinki. Proceedings... Helsinki: RIL, 2011. Theme 1: World Resources.

VARINI, C. ECOENVOLVENTES R \& D. Passive architectural envelopes high thermal performance and low environmental impact for tropical geo-climatic zones with cultivated native woods and plants. In: WORLD SUSTAInABle BUILDings CONFEREnCE, 2011, Helsinki. Proceedings... Helsinki: RIL, 2011. Theme 3 : Sustainability in developing countries.

VERSELE, A. Feasible sustainable building for a small development project in South East India. In: WORLD SUSTAinable BUildings CONFEREnCE, 2011, Helsinki. Proceedings... Helsinki: RIL, 2011. Theme 3 : Sustainability in developing countries.

WALDEN, G.; FABIAN-LOPEZ, A. S. Refurbishment considering environmental impact reduction targets: a test case for a multiple family dwelling in the area of Playa de Palma, Mallorca. In: WORLD SUSTAINABLE BUILDINGS CONFERENCE, 2011, Helsinki. Proceedings... Helsinki: RIL, 2011. Madrid Best Papers, 2011

WOO, L. C. Ecomimesis: a 21 Century Model for a Sustainable Built Environment Based on Nature's Ecosystems. In: WORLD SUSTAINABLE BUILDINGS CONFERENCE, 2011, Helsinki. Proceedings... Helsinki: RIL, 2011. Theme 1: World Resources.

\section{ACKNOWLEDGEMENTS}

Thanks to the representatives of the national masonry associations who responded to my request on how the masonry industry is responding to the desire for more sustainable materials and buildings.

\section{DADOS DOS AUTORES}

(i) President and CEO, Brick Industry Association, United States of America. borchelt@bia.org 